\title{
Revitalization of Library Space Function in Digital Era: Comparative Study of Library Space in TEMPO's Data and Analysis Center and Library of Universitas Indonesia
}

\author{
Nuning Kurniasih \\ Program of Library and Information Science, Department of Communication \& Information \\ Faculty of Communication Science, Universitas Padjadjaran \\ Email: nuningkurniasih@yahoo.com ; nuning.kurniasih@unpad.ac.id
}
Proceedings of The 1st Biannual Congress of International Library, Archives and Information Science Discovery \& Technology 2016, At Universitas Indonesia Depok Indonesia Universitas Indonesia, Depok, 20 Oktober 2016, Pages: 111-121

\begin{abstract}
This study aims to analyze how to revitalize the function of library space in the digital era in order to restore the nature role and function of library as it is, not only as a complementary space in an institution by analyzing: (1) the characteristics of TEMPO's Data and Analysis Center (PDAT) and Universitas Indonesia Library (UI Library), (2) the standpoints and policies of PDAT and UI Library regarding library services in digital era, (3) the role of library in digital era, (4) the formulation of library space in digital era. The method used is qualitative method with the perspective of comparative study. The comparative conducted by analyzing the existence of two library spaces in two different institutions, which are TEMPO's Data and Analysis Center and Library of Universitas Indonesia. The method used to collect data incorporates interviews with the informants from the two institutions, observation, and literature study. The results of the study indicate that (1) the main users of PDAT are journalists and researchers, while the main users of UI Library are UI academics. Both journalists and academics have high degree of information needs. Although PDAT and UI Library are two distinct institutions, both have the same function as the information center and research center, (2) PDAT regards library usage nowadays is no longer about the number of its visitors, but on its utility and continuity values. Thus, it focuses in providing a proper access to the digital information, which is easily accessed, and the library space is no longer significant, meanwhile UI Library argues that the notion of digital library has reduced or even nullify the existence of library space is a misconception. It regards the function of library space is not only as collection repository but also as discussion, meeting and brainstorming space for students in order to produce collaborative study, (3) library roles in the digital era is more than information agent, but also an agent of change through community development (4) there are two ways to keep the existence of library, namely technology adaptation and services innovation. The formulation of library space should generate value added, which will keep the users utilizing library space, thus the revitalization of library space is doable.
\end{abstract}

Keywords: Library Space, Roles of Library, Digital Era, Library Services, Innovation, Community Development

\section{Background}

The fastest access of information on the internet has affected the visitor numbers in library as shown in the data reported by UK's Department of Cultural, Media, and Sports (DCMS). It is reported that since the year of 2005 to 2013, the number of adults visiting library has declined from $48 \%$ to $36 \%$, which lead to the shutdown of around 350 libraries since April 2013 (National Geographic Indonesia, 2013). In Indonesia, the head of General Bureau of National Library, Imam Nurhadi, states that the number of libraries in Indonesia has been increasing, unfortunately the limitedness of books collection has caused the decreasing number of visitors who come and read at the library (Nurhandoko, 2015). It shows the distinct condition in Indonesia and UK. While in UK the decreasing number of library visitors has resulted in the decreasing number of libraries, the opposite condition happened in Indonesia, although the 
number of library visitors has constantly decreased, but the number of library has slowly increased.

Many aspects have affected the decreasing number of library visitors, including in term of collection completeness, the services swiftness, and the affordability of library location. The advance of technology plays a significant role in the dissemination of information nowadays. Internet is capable of indexing and storing abundant information and providing it instantly to those who need it. Besides, once it is connected, internet is easy to access anywhere and anytime, also provides the users with real time connection. Those values attract people to switch to internet and become dependent on it as their main information and communication media. This phenomenon is shown by the findings of GFK Global Research Foundation and Indonesian Digital Association in 2015, which indicate the consumption of news using online media has reached $96 \%$ (Ali, 2016), meaning only 4\% consumes news from offline media. Other finding shows that "while book loans have fallen slightly, internet usage has risen sharply. The total number of loans in 2009 was 48 million plus renewals. In addition, there was an increasing number of downloads - 7.4 million in total-while there were 26 million visits (homepages and bibliotek.dk)" (Niegaard, 2011).

In other words, people consider internet as a more complete and more accessible information source than library because of its easiness and velocity of information access. Thus, it leads to the decreasing number of library visitors.

The advance of technology has caused some institutions to reduce the size of its library space, such as TEMPO's Data and Analysis Center (PDAT). PDAT is a division which responsible to manage the overall data of Tempo Media Group, both text archives and pdf files of its magazines, newspapers, photographs, info graphics, and videos since 1971 (Tempo Media Group, 2016). In 2005, PDAT upgraded its competence by executing studies, analysis, and researches (Priatna, 2016). Then, since 2012 PDAT launches various digital products to perform wider information dissemination (Tempo Media Group, 2016). The head division of PDAT claims that the current priorities are the utility and continuity values including the services of many to many, efficiency, faster access, more productive human resources, 24 hours/ 7 days services, and digitalization. Therefore, the library space at Tempo is used merely as symbol, not operating as a fully functional library. The library of Tempo is only a small space with few numbers of old collections. The information sources of Tempo have been digitalized and available to be accessed by journalists and others through internet (Priatna, 2016).

Nevertheless, there is also institution, which has expanded its library space such as the Library of Universitas Indonesia (UI Labrary). Universitas Indonesia (UI) considers library as a learning facility component where its scholars and academics can meet and interact to develop ideas which lead to interdisciplinary join researches. Therefore, in 2010 UI built a big and fancy building as its library. Besides, this integration aims to increase efficiency of the overall aspects, such as collection procurement and human resources maintenance (Perpustakaan Universitas Indonesia, 2016). A senior librarian of UI Library, Clara Naibaho, in an interview with the researcher states that the mindset of digital library means space saving is a misconception. In this modern era, the library should be functioned as a learning space and meeting point, thus it needs a larger area. Meanwhile the allocation space for collection store has changed where the space allocation for books collection used to take almost the whole space of library, but now its the opposite, a larger space of the library is provided as an area for discussion, meeting, brainstorming purpose, etc (Naibaho, 2016). Luki Wijayanti, former head of UI Library, once made the same statement that the initial reason UI built a huge library building was to provide a public facility for the academics, both insiders and outsiders (Administrator E-Library Nusa Mandiri, 2010). A survey done by Danish in 2004 to 2005 shows that other than to read and to borrow books, more than $50 \%$ of library visitors visit 
library to meet, to study, to work, and to take advantage of the many other services offered (Niegaard, 2011). In other words, library visitors expect more other functions from a library.

PDAT and UI Library are two different institutions. While PDAT is a part of media organization, UI Library is a part of an education institution. However, both have users with high degree of information needs and fast access. The distinct policy by these two different institutions based on two different solid reasons.

Based on the aforementioned background, researcher intrigued to analyze how to revitalize the function of library space in the digital era in order to restore the nature role and function of library as it is, not only as a complementary space in an institution.

\section{Research Goals}

This research conducted with specific goals, as follows:

1. To elaborate the characteristics of PDAT and UI Library.

2. To elaborate the standpoints and policies of PDAT and UI Library regarding library services in digital era.

3. To identify the role of library in digital era.

4. To investigate the formulation of library space in digital era.

\section{Literature Review}

The goals of library services, particularly public library, "are to educate, to provide information, personal development, creating and strengthening reading habits, cultural development, public space and meeting place, positive agency for change in the community, freedom of information, access for all" (International Federation of Library Associations and Institutions Ed. for the Section of Public Libraries by Philip Gill et. al. -, 2001).

The advance of technology has affected the needs of library space. Graham Walton (2014) argues that since 2010 the application of technology in library resulted in the decreasing needs of front line desks for library services. It is the impact of the open access publishing existence, cloud computing, online social network, cross disciplinary research teams, policy developments and funding body mandates, increases in scholarly outputs in many fields, ability to share large amounts of research data, rise of digital humanities.

There are some findings on the library physical space, as follows:

1. A case study in Loughborough University Library, UK, suggests that the needs of library usage including collaborative study, individual study, social space, intrusions and interruptions, use of technology, diversity, library staff/library materials and spatial organization (Bryant, Matthews, \& Walton, 2009).

2. Elizabeth Jordan and Tanya Ziebell reported twelve key findings, including that respondents visited the library to undertake individual study-related activities, to undertake social or group learning activities, they chose to work in the library because it is conveniently located and provides good study spaces, they put location, atmosphere, study space, and finding what they need above social reasons (e.g., group meetings for visiting the library, students spent most of their time in the library using computers and quiet study spaces, students also used e-mail, the Internet, and Facebook, met and chatted with friends, ate, and borrowed books, students wanted the library to provide more computers and more quiet areas. (Webster, 2010)

3. Robert A. Seal argues that academic library needs to provide space for information commons, learning commons, research commons, etc. in response to user needs for access to technology, group work, social interaction, and knowledge creation (Seal, 2014) 
These findings indicate that library users can expect more from a library, which to provide individual and social space for study purpose, to do research, to relax, to work, and to interact in groups.

To accommodate the users expectation, library needs to improve its services. There are some strategic innovation approaches, namely (1) "Starts with the end in mind" - identifies long-term opportunities and then "bridges back to the present" (2) Assumes a rule-breaker (revolutionary) posture (3) Seeks to create new competitive space (4) Seeks breakthrough, disruptive innovation (5) Marries process discipline with creative inspiration (6) Seeks inspiration from unconventional sources (7) Seeks unarticulated consumer needs (8) Is consumer-inspired (9) May experiment with entrepreneurial "new venture" or other organizational structures" (Palmer \& Kaplan, 2015). By employing these innovations, then revitalization of library space is doable.

\section{Research Method}

The method used is qualitative method with the perspective of comparative case study. "Comparative case studies involve the analysis and synthesis of the similarities, differences and patterns across two or more cases that share a common focus or goal" (Goodrick, 2014) . On this research, the comparative conducted by analyzing the existence of two library spaces in two different institutions, which are TEMPO's Data and Analysis Center (PDAT) and UI Library. The method used to collect data incorporates interviews with two informants from the two institutions, observation, and literature study.

The research process based on the method and research design of case study by Robert K. Yin (2014), namely (1) clarify the key evaluation questions and the purpose of the evaluation, (2) identify initial propositions or theories, (3) define the type of cases (4) Define how evidence will be collected, analysed and synthesized, (5) consider and test alternative explanations for outcomes (6) Report findings.

\section{Results and Discussion}

\section{The Characteristics of PDAT and UI Library}

The characteristics of PDAT and UI Library briefly shown in Table 1 as follows:

Table 1

Characteristics of PDAT and UI Library

\begin{tabular}{|c|c|c|}
\hline Elements & PDAT & UI Library \\
\hline Institution & Media & Education \\
\hline Functions & Data Centre; Research Centre; Publishing & $\begin{array}{l}\text { Information Sources, Education and Learning } \\
\text { Facility, Research, Public Services, Recreation. }\end{array}$ \\
\hline Facilities & $\begin{array}{l}\text { SIMT (My SQL, Apache, PHP, dll). } \\
\text { store.tempo.co }\end{array}$ & $\begin{array}{l}\text { Online Public Access Catalog, Internet Access, } \\
\text { Reading Room, Discussion Room, Exclusive } \\
\text { Study Room/Ruang Belajar Khusus (Kubikus), } \\
\text { Locker, MKIOSK (self service for books } \\
\text { borrowing and returning) Book drop (self } \\
\text { service for book returning), Book Dispenser } \\
\text { (online books borrowing services). }\end{array}$ \\
\hline Services & $\begin{array}{l}\text { - Data Centre: Mobile Digital; Digital Archive } \\
\text { of Tempo Media Group. } \\
\text { - School of Photography } \\
\text { - Research Centre: Market Research; Media } \\
\text { Tracking, Awarding, Product Research. } \\
\text { - Publishing: Publisher Services, E-Book/E-Pub, } \\
\text { Book Publisher }\end{array}$ & $\begin{array}{l}\text { Reference Services, Literacy Program, } \\
\text { Circulation }\end{array}$ \\
\hline Collections & $\begin{array}{l}\text { Photo Stock, Photo Contributor, Multimedia } \\
\text { Archive, E-Pub, Info graphics, Cartoon, Book, } \\
\text { Research Findings, Video }\end{array}$ & $\begin{array}{l}\text { UI Papers, Dissertation, Thesis, Mini-thesis, } \\
\text { Textbooks, Reference Books, Magazines, } \\
\text { Journals, Seminar Proceedings, Bulletin, } \\
\text { Journal Articles Index, Multimedia, MPKT B } \\
\text { Books, E-book Scripts, Classic Books }\end{array}$ \\
\hline Users & $\begin{array}{l}\text { - Internal Stakeholders: Employees Journalist, } \\
\text { Management, Shareholders. }\end{array}$ & $\begin{array}{ll}\text { - } & \text { UI Academics } \\
\text { - } & \text { Open for public }\end{array}$ \\
\hline
\end{tabular}




\begin{tabular}{|l|l|l|}
\hline & $\begin{array}{l}- \text { External Stakeholders: Suppliers, Customer/ } \\
\text { Interested Parties, Partner, Competitor, } \\
\text { Candidates for Employment }\end{array}$ & \\
\hline
\end{tabular}

Data Sources: 1. TEMPO's Data and Analysis Center Profile (Priatna, 2016) 2. Universitas Indonesia Profile

(Perpustakaan Universitas Indonesia, 2016)

Table 1 shows that although PDAT and UI Library are two different institutions, both have the same function, namely as the center of information and research. The main users of PDAT are journalists and researchers, while the main users of UI Library are UI academics. Both journalists and academics have high degree of information needs. While in term of information access velocity, considering the demand of news accuracy and immediacy, journalists need fast access and fast processing of information more than academics. Although in most cases this needs is equally the same for both.

Besides the needs of information and fast access, library users' behavior also need to be investigated. Division head of PDAT, Priatna, describes the flow of photos documentation, which starts from the photographer who takes the photos, then handed to photo editor, to the photo admin/photo drafter, and then finally to the documentalist. Photo then inputted into the photo server. Researcher, designer, and redactor can access those photos in the server by internet (Priatna, 2016). This process explains that the information sources of PDAT mostly accessed by individuals, thus it is possible for users to access it from their own place. Meanwhile, UI Library is designed to be the activity center of UI academics, and according to the informant researcher interviewed, the academics have utilized the space very well, even the space seems to be too crowded (Naibaho, 2016).

In term of collection, both PDAT and UI Library manage multimedia collection. The distinction is, while almost all of PDAT collection has been digitalized so that digital library can be established, UI Library is currently still running a hybrid library concept. Besides, in term of collection storage, PDAT already employed cloud storage thus it needs minimum space, while UI Library is still in need of more space.

\section{The Standpoints and Policies of PDAT and UI Library Regarding Library Services in Digital Era}

Table 2

Strategies/Principles of PDAT and UI Library

\begin{tabular}{|l|l|l|}
\hline & \multicolumn{1}{|c|}{ PDAT } & \multicolumn{1}{c|}{ UI Library } \\
\hline Strategies/ & Utility and Continuity Values: & Library is a public space, main supporting facility for \\
Principles & Many to Many, Efficiency, Faster & brainstorming, interacting, and sporting, focused on managing \\
& Access, More productive human & activities which support human quality developing through \\
& resources, 24 hours/7 days & education and research, providing space and facility as meeting \\
& services, Digitalization & point and common lerning for all academics. \\
\hline Policy & Reduce the size of library space. & Expanded its library space. \\
\hline
\end{tabular}

Data Sources: 1. TEMPO's Data and Analysis Center Profile (Priatna, 2016) 2. Universitas Indonesia Profile

(Perpustakaan Universitas Indonesia, 2016)

According to Table 2, PDAT regards library usage nowadays is no longer about the number of its visitors, but on its utility and continuity values. The strategies PDAT employs to achieve those two values are by changing its information dissemination from one to many into many to many, efficiency, speed, more productive performance, 24 hours/7 days services, and transforming all analogue information sources into digital ones. PDAT choose cloud storage and digital information services, so the need for space only for server storage and workspace. In other words, PDAT focuses in providing a proper access to the digital information, which is easily accessed, and the library space is no longer significant,

In other hand, UI Library regards library as a public space, thus it needs to provide meeting point and common learning facility for the academics. According to the informant, even though the library can be accessed through internet, it still needs more space to provide 
the users with the devices to access, such as home PC/computer. Unless, the access done by each user's device (Naibaho, 2016). Based on these standpoints, UI provides 100 exclusive study rooms, reading rooms, and discussion rooms on the third floor of the seven-floors building, which equipped with 180 iMacs in the internet room, besides the collection room and other facilities (Perpustakaan Universitas Indonesia, 2016).

Therefore, it can be concluded that the library space concept in digital era depends on the concept and principles designed by each library.

\section{The Roles of Library in Digital Era}

Based on the aforementioned, both PDAT and UI Library are in agreement regarding the other roles a library should provide in this digital era. The changing role of library in the digital era is based on the advance of technology, the development of open library's model and paradigm, as well as library as agent of change (Lougee, 2002).

The advance of technology has raised the library users expectation of services velocity, easy access, communication openness, and collection completeness. Library has to accommodate those expectations by adjusting itself to the advance of technology. In other hand, the advance of technology emerges the model and paradigm of open library where information sources can be accessed, shared, and discussed, which produces online collaboration. Indeed, in developing an open library, a library needs to pay full attention on the applied regulations, such as intellectual rights.

Library is a place to study and the symbol of civilization. Library enables people to meet, brainstorming, sharing thoughts, and generating new ideas. Library can change the world by providing information sources, which stimulate the users creativity. Library is not merely a place to read or borrow books, but also a space to socialize and to find new values of life. Library provides knowledge, skills, and hopes for a better future. The library's ability in providing accessible information sources through information technology, both online and offline, causing the shift in library's roles, where it is not only about accessibility and availability of information, but also about how people utilize the information to improve one's life.

\section{The Formulation of Library Space in Digital Era}

The concept of library space is significantly dependent on the designed concepts and principles of each library. In this study, there are two distinct institutions, where one is a profitoriented institution and the other is non-profit institution.

In the case of profit-oriented institution, the services value is not only focused on fast, easy, accurate, and efficient services on the usage aspect, but also on the revenue aspect. Therefore, the library space formulation for profit institution needs to consider the revenue for institution itself. While for the non-profit institution, the library space formulation can be employed based on the designed concept or principles without have to considering the revenue. The library space formulation will determine the library usage, thus the library revitalization can be performed.

There are at least two ways to keep the existence of library, namely technology adaptation and services innovation. Technology adaptation includes technology aspect and human resource readiness in utilizing the technology, while the innovation consists of the efforts to perform something new in order to gain targeted market.

Innovation strategy started by identifying the opportunities and challenges in the future which presented by the institution's vision. In this digital era, the institution's vision has to accommodate technology advances and people needs of long life learning. The vision then generates library's missions, which including new roles and functions of library, such as library as learning place, individual and community development, including people empowerment in 
utilizing information sources to get some life values added. This value added offered by library supposed to support the library to be able to compete in digital era. The nowadays library is not only required to provide accessible information, but also required to provide learning space for individuals and groups, discussion space, collaborate, socialize, relax with the other users, and space for special events held by the library itself. Library continues to seek for inspiration to satisfy the users expectation by improving its human resources. Library can choose whether to provide a full digital services or hybrid services, and then allocate the resources in accordance with the principles or the targets desired. Eventually, library should take role in reducing the digital gap and in the digital literacy efforts.

Briefly, the formulation of library space on digital era can be seen in Figure 1.

Figure 1

Library Space Formulation on Digital Era

\begin{tabular}{|c|}
\hline Institution's Vision \\
\hline $\begin{array}{c}\text { Concepts and principles of each institution: } \\
\text { accommodate technology advances and people needs of } \\
\text { long life learning. }\end{array}$ \\
\hline $\begin{array}{c}\text { New roles and functions of library: library as learning } \\
\text { place, individual \& community development and } \\
\text { reducing digital gap. Including people empowerment in } \\
\text { utilizing information sources to get some life values } \\
\text { added }\end{array}$ \\
\hline \multicolumn{2}{|c|}{ Librarv's Mission } \\
\hline Innovation on Library's Program \\
\hline - Seek for inspiration to satisfy the users expectation. \\
\hline - Value added offered by library supposed to support \\
the library to be able to compete in digital era. \\
- Generate value added, which will keep the users \\
utilizing library space.
\end{tabular}

The formulation of library space should generate value added, which will keep the users utilizing library space. Once a library can create a proper library space formulation, then the library revitalization can be achieved.

\section{Conclusion}


The advance of information technology has strengthened as well as transformed the role of library as information center into learning and socialize center. The main role of library is not merely as an information agent, but also as an agent of change through community development. Therefore, nowadays a library is required to not only satisfy its users' information needs, but also to provide individuals and social space to learn, doing research, to relax, to work, and to interact in groups. A library is expected to provide spaces for individual and community development, including provide space for individual study, collaborative study, common rooms, meeting rooms, meeting point, as well as technology equipment needed. Library needs to respond to the era changes and people's behavioral changes positively in order to be fully functioned.

\section{References}

Administrator E-Library Nusa Mandiri. (2010, Agustus 31). Pembangunan Perpustakaan UI. Retrieved from Nusa Mandiri E-Library (Perpustakaan Online Nusa Mandiri): http://elibrary.nusamandiri.ac.id/berita-62-.html

Ali, S. (2016, March 19). Konten Sosial dan Hiburan Jadi Konsumsi Berita Favorit. Retrieved September 6, 2016, from http://swa.co.id/swa/trends/business-research/konten-sosial-dan-hiburan-jadi-konsumsi-berita-favorit

Ashraf, T., \& Gulati, P. A. (2012). Design, Development, and Management of Resources for Digital Library Services Advances in Library and Information Science. Hershey, PA: IGI Global.

Bennett, S. (2005). Righting the Balance. In C. o. Resources, Library as Place: Rethinking Roles, Rethinking Space (pp. 1024). Washington, D.C.: Council on Library and Information Resources.

Bryant, J., Matthews, G., \& Walton, G. (2009). Academic Libraries and Social and Learning Space: Case Study of Loughborough University Library, UK. Journal of Librarianship and Information Science vol. 41 no. 1 7-18, March, 7-18.

Du, Y. (2016). Small Libraries, Big Impact: How to Better Serve Your Community in the Digital Age: How to Better Serve Your Community in the Digital Age. Santa Barbara, CA: ABC-CLIO.

Frischer, B. (2005). The Ultimate Internet Café: Reflections of a Practicing Digital Humanist about Designing a Future for the Research Library in the Digital Age. In C. o. Resources, Library as Place: Rethinking Roles, Rethinking Space (pp. 41-55). Washington, D.C.: Council on Library and Information Resources.

Goodrick, D. (2014). Comparative Case Studies (Methodological Briefs Impact Evaluation No. 9). Florence, Italy: United Nations Children's Fund (UNICEF) .

Hantrais, L. (1995). Comparative Research Methods. Social Research Update Issue 13 Summer, http://sru.soc.surrey.ac.uk/SRU13.html.

Hawkins, B. L. (2011, September-October). Information Access in the Digital Era. Educause Review, pp. 51-57.

International Federation of Library Associations and Institutions Ed. for the Section of Public Libraries by Philip Gill et. al. (2001). The Public Library Service: IFLA/UNESCO Guidelines for Development. München: Saur.

Jadhav, V. G. (2012). Integration of Digital Reference Service for Scholarly Communication in Digital Libraries. In T. Ashraf, \& P. A. Gulati, Design, Development and Management of Resources for Digital Library Services (pp. 13-20). Hershey, PA: IGI Global.

K.Yin, R. (2014). Case Study Research: Design and Methods, fifth edition. Los Angeles: Sage.

Lee, S. H. (2013). Print vs. Digital: The Future of Coexistence. London: Routledge.

Lougee, W. P. (2002). Diffuse Libraries: Emergent Roles for the Research Library in the Digital Age. Washington, D.C.: Council on Library and Information Resources.

Matthews, G., \& Walton, G. (2013). University Libraries and Space in the Digital World. Farnham: Ashgate: Ashgate.

Matthews, G., \& Walton, G. (2014). Strategic development of university library space: Widening the influence". New Library World, Vol. 115 Iss: 5/6, 237-249.

Mills, M., Bunt, G. G., \& Bruijn, J. d. (2006). Comparative Research: Persistent Problems and Promising Solutions. International Sociology Vol 21(5): 619-631 September, 619-631.

Naibaho, C. (2016, August 18). Alasan Perpustakaan Universitas Indonesia Membangun Gedung Besar di Era Digital. (N. Kurniasih, Interviewer)

National Geographic Indonesia. (2013, September 29). Di Inggris, Jumlah Pengunjung Perpustakaan Menurun. Retrieved from National Geographic Indonesia: http://nationalgeographic.co.id/berita/2013/09/di-inggris-jumlah-pengunjungperpustakaan-menurun

Niegaard, H. (2011). Library Space and Digital Challenges. LIBRARY TRENDS, Vol. 60, No. 1, 174-189.

Nurhandoko. (2015, May 8). Nurhandoko. 2015. Pengunjung PerPengunjung Perpustakaan Menurun Akibat Koleksi Buku Kurang. Retrieved from Pikiran Rakyat: http://www.pikiran-rakyat.com/jawabarat/2015/05/08/326532/pengunjung-perpustakaan-menurun-akibat-koleksi-buku-kurang.

Palmer, D., \& Kaplan, S. (2015). Innovation, A Framework for Strategic Inovation: Blending Strategy and Creative Exploration to Discover Future Business . San Francisco CA, USA: InnovationPoint LLC .

Perpustakaan Universitas Indonesia. (2016). Profil Perpustakaan Universitas Indonesia. Retrieved from Universitas Indonesia Library; The Crystal of Knowledge: http://lib.ui.ac.id/profil.jsp?hal=3 
Peterson, C. A. (2005). Space Designed for Lifelong Learning: The Dr. Martin Luther King Jr . Joint-Use Library. In C. o. Resources, Library as Place: Rethinking Roles, Rethinking Space (pp. 56-65). Washington, D.C.: Council on Library and Information Resources .

Priatna. (2016, August 3). Pusat Data dan Analisa Tempo. (N. Kurniasih, Interviewer)

Rickinson, M., \& May, H. (2009). A Comparative Study of Methodological Approaches to Reviewing Literature. US: The Higher Education Academy.

Seal, R. A. (2014). "Library Spaces in the 21 st Century-Meeting the Challenges of User Needs for Information, Technology, and Expertise. The 7th Shanghai International Library Forum, July 11. Shanghai, Cina: Faculty Publications at Loyola eCommons.

Sulaeman, R. J., Taalbeh, S. A., \& Ahmed, M. H. (2015). Changing Functions of Libraries and Publisher in The Digital Information Sources Environment . International Journal of Library and Information Science Vol. 7 (4), 86-90.

Tempo Media Group. (2016). PDAT (Pusat Data dan Analisa TEMPO). Retrieved from Tempo Media Group: https://korporat.tempo.co/pdat/produk

Walton, G. (2014, August 21). Developing and Enhancing Library Physical Space: The Challenges Posed By The Digital Library. FGV, Rio de Janeiro, Brazil.

Webster, K. (2010, November-December). The Library Space as Learning Space. Educause Review. Creative Commons Attribution-NonCommercial-NoDerivs 3.0 License (http://creativecommons.org/licenses/by-ncnd/3.0/).

Yanow, D. (2014). Interpretive Analysis and Comparative Research. In I. Engeli, C. Rothmayr, \& eds., Comparative Policy Studies: Conceptual and Methodological Challenges (pp. 131-59). Palgrave : Macmillan.

Yin, R. K. (2014). Case Study Research Design and Methods (5th ed.). Thousand Oaks, CA: Sage.

Yoo-Lee, E., \& Kim, K.-S. (2013). Libraries as Media: Redefining a Library in the Digital Age. IFLA WLIC 2013. Singapore: IFLA.

Zickuhr, K., Rainie, L., \& Purcell, K. (2013). Library Services in the Digital Age. Washington, D.C. 20036: Pew Research Center's Internet \& American Life Project. 